under certain conditions, the assayer's balance may sometimes oscillate and quickly change its zero is understood. Possibly these air currents may indirectly have led to the abandonment of the Cavendish experiment at Cambridge, and explain why a very well-constructed horizontal pendulum is never quite at rest.

One very important piece of knowledge for the seismologist lies in the fact that these so-called tremor; can be stopped by using covering cases through which air can circulate, but above all by working in a room that is almost draughty with ventilation. Sometimes a room will be found which it seems impossible to cure, whilst in the adjoining one, for reasons not quite clear, the same instrument will always remain at rest.

It seems as if there existed in rooms which may be fairly similar in appearance slight physical differences of the walls, the floors and ceilings, as, for example, with regard to dampness; so that in one room, in consequence of differences of temperature, power of desiccation and other properties between the different boundaries, we may have a slow circulation of air estab. lished which is inappreciable in an adjoining room. Whether this is the true explanation of the seismic bogey remains for more careful demonstration, but already the writer has learned that with draughty surroundings an instrument will remain at rest, whilst when this condition is neglected, what is apparently a slow and steady circulation of the atmosphere will cause motion. We yet wish to know why these troublesome visitors appear with such regularity at certain hours and seasons (see Fig. 9). One result of what we have learned is that now hundreds of feet of bromide paper have been saved from blackening, and unfelt earthquakes, which otherwise would have been eclipsed, have been clearly recorded.

In the above few notes all that is attempted is to give a scanty outline of the more important branches of work which at present attract the attention of the working seismologist. Other investigations which it is desirable to make relate to the irregular changes in level which are completed in a few minutes or several days, and above all those grander movements, the results of which are exhibited on the surface of our earth in the formation of continental domes and mountain ranges, together with those activities hidden from our view, which have been referred to as processes of secular flow and crush -in all of which we see the parentage of the earthquake.

J. Milne.

\section{THE CAMBRIDGE EXPEDITION TO TORRES} STRAITS AND BORNEO.

DURING the preparation of a monograph on the anthropology of the Torres Straits islanders, I found the notes I had previously made were unsatisfactory on so many points that I decided to go out again in order to render them as complete as possible, though probably a great deal is by this time irretrievably lost.

A Committee of prominent members of the University of Cambridge is co-operating with me, and part of the cost of the expedition will be defrayed by a grant from the Worts' Fund, which is administered by the University -

The expedition will be almost entirely anthropological in character, but the land flora and fauna will not be neglected, and certain geographical observations will also be made.

The other members of the expedition are Dr. W. McDougall, Fellow of St. John's College, Cambridge, and of St. Thomas's Hospital, London; Dr. C. S. Myers, Caius College, Cambridge, and St. Bartholomew's Hospital, London; Mr. S. H. Ray, Dr. W. H. R. Rivers, St. John's College, Cambridge, Lecturer on Experimental Psychology at Cambridge and at University College, London; Dr. C. G. Seligmann, of St. Thomas's Hospital; and Mr. A. Wilkin, of King's College, Cambridge.

$$
\text { NO. I } 47 \hat{3} \text {. VOL. } 57]
$$

The work of the expedition will be distributed as follows :-I shall be responsible for the observations on the physical characters of the natives; their language and phonology will be studied by Mr. Ray. Mr. Ray, who has a world-wide reputation as an authority on the languages of Oceania generally, has already made a very careful study of the languages of Torres Straits " A Study of the Languages of Torres Straits, with Vocabularies and Grammatical Notes," Proc. Roy. Irish Acad. (3), ii., I893, p. 463 ; iv., I897, p. II9). Drs. Rivers, McDougall and Myers will initiate a new departure in practical anthropology by studying comparative experi. mental psychology in the field. They will test the senses and sensibility of the natives as far as it will be possible under the local conditions, and make whatever observations they can on the mental processes of the natives. Dr. Myers will also pay especial attention to native music, and I shall continue my researches on the decorative art of British New Guinea.

The hygienic and medical aspects of anthropology will be studied by the four qualified medical men. The sociology of the natives, including such subjects as re. lationships, ownership, land tenure, descent of property, and the like, will be investigated by Mr. Wilkin. All the old legends that can be collected will be recorded, and an endeavour will be made to recover the old beliefs of the people. Other departments of anthropology will also be studied. Dr. Seligmann will act as naturalist to the expedition; one of his duties will be to identify all the animals and plants which are utilised by the natives in any way.

Besides the ordinary instruments for anthropometry, there will be a small, carefully selected, collection of apparatus for experimental psychology. Two mechanical phonographs will be taken to record the native songs, music and languages. There will also be a complete photographic equipment, including a cinematograph for reproducing native dances, ceremonies, and certain characteristic actions.

The main object of the expedition is to continue and, as far as practicable, complete the earlier observations made in Torres Straits ; but, for the sake of comparison, it is hoped that observations will be made on Australians, Papuans, Melanesians and Polynesians, as opportunities present themselves. After spending a few months in the Straits a short visit will be paid to the mainland of New Guinea, in order to trace the relationship of the islanders.

Some of the party will then have to return home; but the remainder have accepted a very generous and enthusiastic invitation to visit $\mathrm{Mr}$. C. Hose, the Chief Magistrate of the Baram District of the Raj of Sarawak. Mr. Hose, who is a Cambridge man (Jesus College), is a keen naturalist and has a very wide knowledge of the natives and their languages, and has a warm sympathy for the people themselves; consequently the expedition will have exceptional facilities for seeing something of the inland tribes of Borneo, and interesting comparisons may be expected between the different races which the expedition will have under observation.

The expedition will start about March 2, and will return early in the summer of 1899 .

Any suggestions as to lines of investigation or methods of study will be gladly welcomed. If the curator of any museum or collection desires information respecting ethnographical objects from Torres Straits or British New Guinea, and sends sketches or photographs of such objects to me (Inisfail, Hills Road, Cambridge; or Thursday Island, Torres Straits, Queensland), I will take the illustrations with me, and will endeavour to obtain the required information at the spot where the objects were obtained. I shall also be pleased to make, as far as I am able, any special inquiries that any ethnologist may require.
Alfred C. Haddon. 